\title{
Sustainability Comparison Between Organic and Conventional Systems at Farm and Field Scale: A Case Study in Olive Production Systems in Apulia Region
}

\author{
Xhevaire Dulja ${ }^{1}$, Jenny Calabrese ${ }^{2}$, Cesare Pacini ${ }^{3}$, Concetta \\ Vazzana $^{3}$ and Mariana Nikolla ${ }^{4}$
}

\begin{abstract}
:
Dependence of conventional agricultural systems on chemical fertilizers and pesticides makes agricultural systems less stable and important drift polluters influencing to the regional and global sustainability. This problem made human being think about the alternative systems: agricultural systems that mimic natural systems and are friendly to the environment; those have higher economical efficiency concerning production level and costs. The objective of the present study was sustainability assessment and comparison of organic and conventional system with special focus environmental and economical performance. The case study consisted of two organic and conventional olive producing farms in the South of Italy. The method used for sustainability assessment was Environmental Accounting Information System (EAIS) that integrates together environmental (soil organic matter, soil erosion, genetic and landscape biodiversity, EPRIP, etc ) and economical indicators (gross margin). Data used for assessment of EAIS indicators values were mainly collected from: farm economic-accounting systems, interviews, farm maps, area public organizations, bibliographical sources, farm nutrient accounting systems, observations and field assessments and chemical soil analyses. The indicator values measured into two farms were compared to theoretical or reference indicator values. Based on indicator assessment it was concluded that organic olive growing farm had better performance than conventional farm.
\end{abstract}

Key words: Environmental accounting information system, sustainability, organic, agriculture, conventional.

${ }^{1}{ }^{*}$ corresponding author Agricultural University of Tirana , Economy and Agribusiness Faculty, Rural Tourism Management Department, Tirana- ALBANIA;

${ }^{2}$ Mediterranean Agronomic Institute of Bari, Bari-ITALY;

${ }^{3}$ University of Florence, Department of Plant Production, Soil and Agroforestal Environment Sciences, Florence-ITALY;

${ }^{4}$ Agricultural University of Tirana, Economy and Agribusiness Faculty, Mathematics and Informatic Science Department, Tirana- ALBANIA. 


\section{Introduction}

Agriculture has an important share into environmental pollution and natural resources degradation (biodiversity reduction, soil degradation, etc) through use of chemicals (fertilizers and pesticides), monocultures, use of a limited number of plant species and seeds, etc.

Alternative techniques and agricultural systems are experimented and analyzed to find the best practices that contribute to sustainability: researchers to understand mechanism for a broader diffusion to practitioners and policy makers; policy-makers for their local policies and advisors for their advising work. Scientists are interested more on non condensed data, policymakers need condensed data to relate them with policy objectives and the farmers need concrete and detailed data taking into account local pedo-climatic and production conditions for their farm evaluation in accordance with threshold values coming from policy objectives (Pacini, 2003).

Comparison with organic agriculture as the most frequent research has shown various results regarding environmental and economical performance. There are known different assessment methods that measure the sustainability and differ between them mainly on goal of assessment, logical relation between indicators, spatial level and reference system used for comparison. Most of research has been focused on indicators that represent community level and can be used by policy-makers for community level planning and programs, but that can not be measured and give information to single farms on the sustainability of their agricultural techniques and managing decisions.

Alternatively, the Environmental Accounting Information System (EAIS) method was developed to serve to different spatial levels, production and pedoclimatic factors (Pacini et al., 2011). It offers valuable data for all actors such as scientist, farmers and policy-makers. Indicators of EAIS are site-specific and can be used for comparison purposes at site/field levels and at the same time they can be aggregated to be used at farm and upper levels (Fig.1).

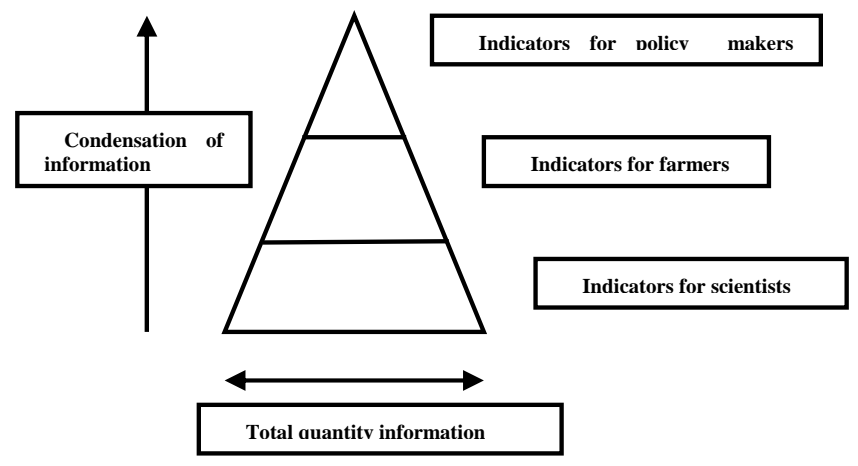

Figure 1.: Relationship between indicators (Source: Braat, 1991) 
The EAIS, is a method developed first in 1991 by Pileri, (1992), Vazzana et al., (1997), Vereijken, (1999) and lastly by Pacini et al., (2003). It is the previous version of Environmental Sustainability Information System (AESIS) developed further for assessment at ordinary farm level (Pacini et al., 2011).

EAIS is called like this as an analogy to a balance sheet and the income statement in a financial accountancy. As the financial balance sheet the EAIS "balance sheet" is assessed once a year. A set of environmental indicators can be assessed annually and can give data for space (between farms in an area or with reference system) and time comparisons (comparison in time inside the same farm).

Changes between two balance sheet assessments are reported in the environmental profit-loss account and correspond with the flows of the environmental capital during the year. Flow indicators measure changes in profitloss account and correspond to depreciations (costs) and appreciations (revenues) of the assets. They can be calculated directly, summing all appreciations and depreciations, or as a change between two balance assessments of two consecutive years. But it is not possible to do the contrary, an computation of a stock indicator starting from a flow indicator. This means we can not do always the calculation of both stock and flow indicators for each environmental process.

The EAIS can be organized into environmental systems and modules. The systems considered are: water, soil, production activities, flora e fauna, nitrogen balance, phosphorus balance, pollution and demand for non-replaceable energy. Indicators used can be grouped into stock and flow indicators.

Each farm has to be divided into sites which are geographic areas that have homogenous form of land, water table level, soil type and climate. Data have to be collected and record cards have to be completed for each site.

The objective of the present research was to assess environmental and financial performance and to compare the sustainability of two olive growing farms, conventional and organic, located in Apulia region in the South of Italy.

\section{Methodology}

\subsection{Case study farms}

The case study area is located in the south part of Italy, in Apulia region. Apulia region is mentioned for olive and grape growing; for olive oil and wine production. One of the characteristics of this region is that olives are spread on large plantations and generally speaking, its landscape is uniform. 


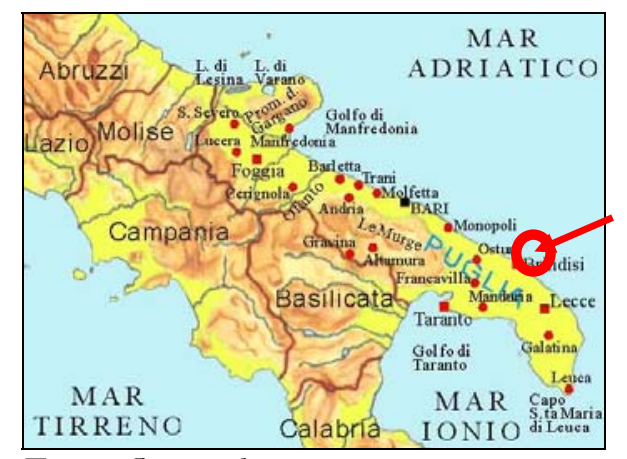

Fig. 2. Case study area

The two farms under study, the organic farm "Serenerba" and conventional "!Il Frantoio", are chosen in Ostuni municipality, an area characterised by olives. Ostuni municipality is located in the Adriatic coastal part of the southern Italy. It has a Mediterranean climate characterised by $678 \mathrm{~mm}$ of annual rainfall and 6.63 ${ }^{\circ} \mathrm{C}$ and $11.97{ }^{\circ} \mathrm{C}$ the respective average annual minimal and maximal temperatures (ACLA 2, 2001). It is a locality where olive growing is a traditional activity and sometimes the very well developed tourism is combined with the agro tourism.

The criteria for selecting the farms were: Farms first had to comprise the main important productions in the area, to have representative types of soil, landform and hydrological conditions of the area and to be market-oriented. Serenerba and Il Frantoio are neighbour farms representing the same pedo-climatic conditions.

Each farm had to be divided into sites which are geographic areas that have homogenous form of land, water table level, soil type and climate. The area of Serenerba was divided into four sites and Il Frantoio was devided into three sites. The respective characteristics for each farm and site are presented in tab. 1. The case-study farms manage to keep the soil covered with herbaceous plants in order to protect the topsoil from erosion. In both farms do not exist terraces and channel network inside the fields and between them to slow down speed of water. Terraces and drainage system are replaced by walls posed along the borders of the fields. They are considered ecological infrastructure for the role they play in slowing down the water speed and as undisturbed areas serve as shelter for organisms contributing in the species biodiversity.

Main olive cultivars found in this area are Ogliarola Salentina, Frantoio, Coratina, Pecholine, Cima di Melfi and Leccina. The organic farm has only secular olives (Ogliarola Salentina), meanwhile the conventional has old and young olives.

Ogliarola Salentina cultivar coming from a very long- term selection favours organic management. 
Tab. 1. Description of the farm sites

\begin{tabular}{|c|c|c|c|c|c|c|c|c|}
\hline \multicolumn{2}{|c|}{ Farms/Sites } & $\begin{array}{l}\text { Land } \\
\text { form }\end{array}$ & $\begin{array}{c}\text { Soil } \\
\text { texture }\end{array}$ & $\begin{array}{l}\text { Slope } \\
(\%)\end{array}$ & $\begin{array}{l}\text { Cultivati } \\
\text { on }\end{array}$ & $\begin{array}{c}\text { Olive } \\
\text { s } \\
\text { Nr. }\end{array}$ & AAU & $\begin{array}{l}\text { Irrigatic } \\
\mathrm{n}\end{array}$ \\
\hline \multirow{5}{*}{ Serenerba } & $\begin{array}{l}\text { Site } \\
1\end{array}$ & $\begin{array}{l}\text { Moderat } \\
\text { ed hill }\end{array}$ & Clayey & $\begin{array}{r}2.4- \\
6.56 \\
\end{array}$ & $\begin{array}{l}\text { Secular } \\
\text { Olives }\end{array}$ & 723 & 18.51 & Irrigated \\
\hline & $\begin{array}{l}\text { Site } \\
2\end{array}$ & $\begin{array}{l}\text { Moderat } \\
\text { ed hill }\end{array}$ & Clayey & $\begin{array}{l}2.13- \\
2.45 \\
\end{array}$ & $\begin{array}{c}\text { Herbaceou } \\
\text { s Plants }\end{array}$ & & 1.49 & $\begin{array}{c}\text { Not } \\
\text { Irrigated }\end{array}$ \\
\hline & $\begin{array}{l}\text { Site } \\
3\end{array}$ & $\begin{array}{l}\text { Moderat } \\
\text { ed hill }\end{array}$ & Clayey & 3.17 & $\begin{array}{c}\text { Horticultur } \\
\mathrm{e}\end{array}$ & & 0.39 & $\begin{array}{c}\text { Not } \\
\text { Irrigated }\end{array}$ \\
\hline & $\begin{array}{l}\text { Site } \\
14\end{array}$ & $\begin{array}{l}\text { Moderat } \\
\text { ed hill }\end{array}$ & Clayey & 11.53 & Forest & & & $\begin{array}{c}\text { Not } \\
\text { irrigated }\end{array}$ \\
\hline & $\begin{array}{l}\text { Tot } \\
\text { al }\end{array}$ & & & & & 723 & 20,52 & \\
\hline \multirow{4}{*}{ Il Frantoio } & $\begin{array}{l}\text { Site } \\
1\end{array}$ & Flat & $\begin{array}{l}\text { Clayey } \\
\text { and } \\
\text { Sandy- } \\
\text { clayey }\end{array}$ & $\begin{array}{l}0.87- \\
2,98\end{array}$ & $\begin{array}{l}\text { Young } \\
\text { Olives }\end{array}$ & 1616 & 10.79 & Irrigated \\
\hline & $\begin{array}{l}\text { Site } \\
2\end{array}$ & $\begin{array}{c}\begin{array}{c}\text { Flat- } \\
\text { moderated } \\
\text { hill }\end{array} \\
\text {. }\end{array}$ & $\begin{array}{l}\text { Clayey } \\
\text { and } \\
\text { Sandy- } \\
\text { clayey }\end{array}$ & $\begin{array}{l}0.27- \\
5.54\end{array}$ & $\begin{array}{l}\text { Secular } \\
\text { Olives }\end{array}$ & 1900 & 35.69 & Irrigated \\
\hline & $\begin{array}{l}\text { Site } \\
3\end{array}$ & Flat & Clayey & $\begin{array}{l}0.63- \\
7.54\end{array}$ & $\begin{array}{c}\text { Herbaceou } \\
\text { s Plants }\end{array}$ & & 2.38 & $\begin{array}{c}\text { Not } \\
\text { Irrigated }\end{array}$ \\
\hline & $\begin{array}{l}\text { Tot } \\
\text { al }\end{array}$ & & & & & 3516 & 48,81 & \\
\hline
\end{tabular}

Pesticides used in the conventional farm are Copper oxycloride, Azinphosmetile, Dimetoate, Phosphamidon, Triclorfon and Gliphosate. Serenerba has done only one treatment with Copper oxycloride. It was trying to manage pest attack (especially against olive fly), using mass-traps of sexual confusion on farm borders and controlling traps within the sites.

\subsection{Data collection and processing}

Record cards contain: preceding crop, yields and prices, compensation and agroenvironmental payments, types of cultivation, useful cultivation periods, labor requirements, productive factors application and prices.

Many data had to be collected before proceeding with the EAIS. Information sources were different such as farm accounting system, interviews with the farmers, regional public organizations, bibliographical sources, farm nutrient accounting systems, farm air photos and maps, observation in field (biodiversity assessment), chemical analyses (used for assessment of stock indicators and

\footnotetext{
${ }^{1}$ The 0,93 ha of site 4 of Serenerba-organic farm are not included in AAU, because it is forest
} 
calculation of flow indicators), hydro-meteorological data from the nearest meteorological station etc. The scheme of samples taken for chemical analyses, in both farms are presented in figures 3 . and 4 ..

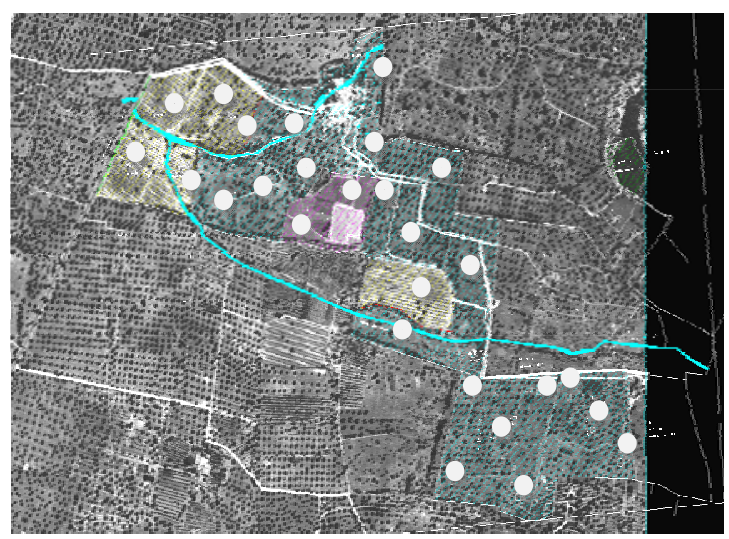

Fig. 3. Il Frantoio farm (conventional)

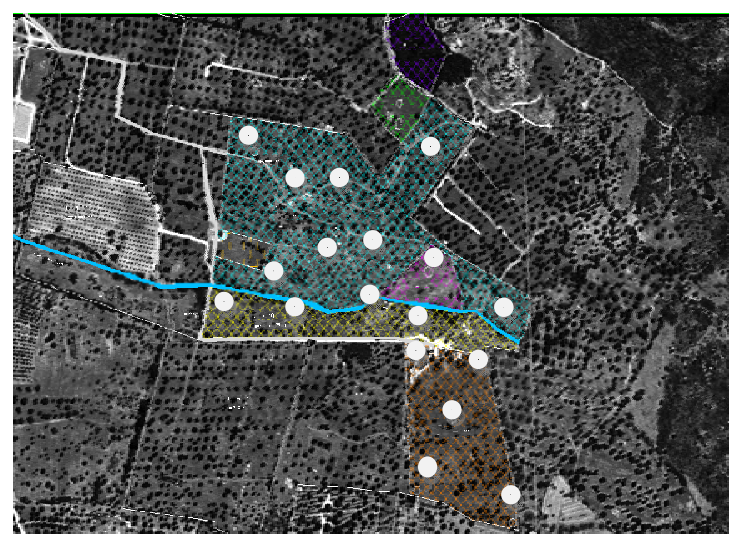

Fig.4. Serenerba (organic farm)

The different formula and softwares are used: AutoCad to measure slopes, plant coverage and to overlap air photo with digital maps; EPRIP program to calculate the pesticide risk (Trevisan et al., 1999 ; Reus et al., 2002 ; Padovani et al., 2004), the Total Station TOPCON 1400 instrument to measure ecological infrastructure and report on maps.

\subsection{Indicators}

Twelve indicators were selected carefully in order to evaluate the state of nine critical points (Tab.2) used in the study able to influence the sustainability of the agro-ecosystem for the majority of olive growers in Apulia region.

A critical point was considered a factor that plays a key role in the system and is a limiting factor for the sustainability of the farm. The level of productivity, quality of the environment and farm incomes on the farm are threatened in case of a bad management and considered critical points.

The Water Use Indicator (WUI) is considered to assess the efficiency of water use on farm and impact of farm activities on water as natural resource. A simplified indicator for water use in each site was calculated with formula (1).

$$
\text { WUI }=(\mathrm{CIA} / \mathrm{CDW}) / \mathrm{AAU}
$$

CIA is the crop irrigation amount used for the site $\left(\mathrm{m}^{3}\right)$,

CDW is the crop demand of water for the corresponding surface $\left(\mathrm{m}^{3}\right)$, AAU is agricultural area used for site (ha)

CIA/CDW is the water use efficiency for the crop and 
CDW is calculated by means of hydrological balance which take into account rooting depth trend, soil coverage by plants, local evapotranspiration potential, rainfall, irrigation system efficiency and soil field capacity.

Table 2: Critical points and respective indicators ( modified from Pacini, 2002)

\begin{tabular}{|c|c|c|c|c|}
\hline \multicolumn{3}{|c|}{ Critical points } & Indicators & $\begin{array}{l}\text { Meth } \\
\text { od } \\
\text { sourc } \\
\text { e }\end{array}$ \\
\hline \multirow{11}{*}{$\begin{array}{l}\text { Environmental } \\
\text { Critical points }\end{array}$} & 1 & Water demand & Water use indicator & {$[1 ; 2]$} \\
\hline & 2 & Soil erosion & Soil erosion & [2] \\
\hline & \multirow[b]{2}{*}{3} & \multirow[b]{2}{*}{$\begin{array}{l}\text { Loss of organic } \\
\text { matter }\end{array}$} & Soil organic matter content & {$[2 ; 5]$} \\
\hline & & & $\begin{array}{l}\text { Soil organic matter } \\
\text { input/output }\end{array}$ & [2] \\
\hline & 4 & $\begin{array}{l}\text { Landscape } \\
\text { diversity }\end{array}$ & $\begin{array}{l}\text { Agricultural landscape } \\
\text { diversity }\end{array}$ & [4] \\
\hline & \multirow{3}{*}{5} & \multirow{3}{*}{$\begin{array}{c}\text { Flora } \\
\text { biodiversity }\end{array}$} & Herbaceous plant biodiversity & [4] \\
\hline & & & Arbour Biodiversity Indicator & {$[2 ; 5]$} \\
\hline & & & $\begin{array}{l}\text { Ecological Infrastructure } \\
\text { Indicator }\end{array}$ & {$[4: 5]$} \\
\hline & 6 & Nitrogen cycle & Nitrogen surplus & [2] \\
\hline & & Phosphorus cycle & Phosphorus surplus & [2] \\
\hline & 8 & $\begin{array}{r}\text { Biocide } \\
\text { pollution }\end{array}$ & $\begin{array}{l}\text { Environmental potential risk } \\
\text { of pesticide use }\end{array}$ & [3] \\
\hline $\begin{array}{l}\text { Economical critical } \\
\text { point }\end{array}$ & 9 & $\begin{array}{l}\text { Financial } \\
\text { situation }\end{array}$ & Gross margin & \\
\hline
\end{tabular}

\section{Legend of Method Source:}

[1] Pacini, 2003; [2] from literature (Wischmeier and Smith, 1978; Allen, 1998; Günsel et al., 2002; Lazzerini et al., 2002; Becher, 2003; Pacini, 2003; [3] EPRIP model used for the calculation of pesticide risk (Reus et al.,1999; Reus and Leendertse, 2000; [4] existing methods which are modified; [5] measurements done from the author on the maps or on terrain and analyses done in the laboratory

The Potential risk indicator for soil erosion is included in soil morphology and structure module. A simple model is used in the case of these farms using the empirical equation of Weschmeier and Smith, which takes into consideration: soil texture and structure, organic matter content in soil, permeability of water in the soil and slope together with soil coverage factor and agronomical practices (Wischmeier and Smith, 1978; Becher, 2003; Lazzerini et al., 2002; USDA, 2001; Saxton, 2003; Ritter, 2004; Van der Knijft at al., 1999).

$$
\begin{aligned}
& \mathrm{A}=\mathrm{R} \times \mathrm{K} \times \mathrm{SL} \times \mathrm{C} \times \mathrm{P} \\
& \text { A- Average Annual Soil Loss [ton/(ha.year] } \\
& \text { R- Rainfall Erosivity factor }[\mathrm{N} / \mathrm{h}]
\end{aligned}
$$


K- Soil Erodibility Factor [ (tons.h)/(ha.N)]

SxL- topographical factor (L-Slope Length Factor [ dimensionless] ;

S-Slope Factor [dimensionless]

C- plant cover factor [dimensionless]

P- agronomical practices factor [dimensionless] (Becher, 2003)

After calculating of the above factors, we can determine the erodibility class of our field, site and farm level. The erosion classes used are five: very low, low, moderate, high and very high. Determination of erosion class can be done using a table constructed with three main elements of the erosion equation ( $\mathrm{R}$ : $\left.\mathrm{R}_{1}, \mathrm{R}_{2}, \mathrm{R}_{3}, \mathrm{R}_{4}, \mathrm{R}_{5} ; \mathrm{S}: \mathrm{K}_{1}, \mathrm{~K}_{2}, \mathrm{~K}_{3}, \mathrm{~K}_{4}, \mathrm{~K}_{5}, \mathrm{~K}_{6} ; \mathrm{S}: \mathrm{S}_{1}, \mathrm{~S}_{2}, \mathrm{~S}_{3}, \mathrm{~S}_{4}\right)$ without calculating a total numerical sum (Lazzerini et al., 2002).

Soil organic matter content indicator is an indicator based on soil analyses. Changes in time of organic matter content were used to evaluate trends of soil fertility and resilience compared with environmental sustainability thresholds found in literature.

Indicator values were calculated starting from soil analysis data. The analyses' protocol was identified according to common methodology used in laboratory of CHIEAM-Bari (Hamdy, 1997). The indicator is calculated for sites and/ for the farms as a weighted mean. The indicator of soil organic matter content measures the level of organic matter in soils and assesses depletion or enrichment related to the farming practices. Increase or decrease of organic matter in time depends from agronomic means like measures for soil protection, minimum tillage practices, ratio between organic matter input/output, etc.

The Agricultural Landscape Diversity Indicator (ALDI) aims to evaluate crop diversification in space. In our case only this indicator is considered from the indicators included in the module of plant production. A diversity index is a mathematical measure of species diversity in a community (Beals et al., 2000). This is an important ecological indicator but at the same time helps to evaluate the landscape from an aesthetic point of view. The formula used to calculate this indicator is the Shannon Index adopted to cultivated land in place of spontaneous species (Pacini, 2003).

$$
H=-\sum_{i=1}^{x} p_{j} \ln p_{j}
$$

(3) (Beals et al., 2000)

H- Shannon index

pi- proportion of individuals of one species with the total individuals

The index is calculated starting from the species share in a given assembly: in this case their shares are respective surfaces. The base to calculate 
the index is Crop Diversity Minimum Area (CDMA). CDMA is the sum of the average field surfaces of each different crop type in the site. Calculating the Shannon Index (see formula 3) on CDMAs and summing the results at site level, we can evaluate crop diversity within the sites taking into account non adjacency among single fields too. The value can be multiplied by a correction factor to evaluate the endangered species growing in each site. Since almost all surfaces of both farms were cultivated with olives there was not a significant value of this indicator.

The Herbaceous Plant Biodiversity Indicator (HPBI) evaluates the state and changes of the environmental capital related to herbaceous plants. HPBI is selected as indicator to assess the environmental critical point that is the biodiversity loss. The indicator is calculated through the Braun-Blanquet method (Myristica 2002; Pacini, 2003). The accounting method of HPBI indicator can be modified compared to the literature cases in order to fit better to the research requirements.

In the Braun-Blanquet modified method, vascular plant diversity can be calculated estimating the percentages of species coverage and their distribution in the plot observed. In this case the vegetation is not studied in layers because there is only one herbaceous plant layer. The Braun-Blanquet modified method divides species into seven different classes according to their cover percentage (See table 3).

The assessment of HPBI consists on species identification and assessment of their coverage in percentage in one homogenous and representative area of 50 square meters. The total sum of the single species scores gives the value of biodiversity indicator at field level.

Table 3: The biodiversity indicator values for each species coverage class (Lazzerini et al 2002).

\begin{tabular}{|lcc|}
\hline Coverage percentage (\%) & $\begin{array}{c}\text { Braun-Blanquet } \\
\text { code }\end{array}$ & $\begin{array}{c}\text { Species Biodiversity } \\
\text { indicator }\end{array}$ \\
\hline Species coverage $80-100$ & 5 & 1 \\
\hline Species coverage $60-80$ & 4 & 2 \\
\hline Species coverage $40-60$ & 3 & 3 \\
\hline Species coverage $20-40$ & 2 & 4 \\
\hline Species coverage $1-20$ & 1 & 5 \\
\hline Species coverage $<1$ & $(+)$ & 6 \\
\hline $\begin{array}{c}\text { Very rare species, presenting only isolated } \\
\text { individuals }\end{array}$ & $\mathbb{B}$ & 7 \\
\hline
\end{tabular}


The biodiversity indicator for each field or for bigger homogeneous areas is taken from the sum of the individual species indicator assessed according to table 3.. It is calculated with the following formula:

$$
H P B I=\sum\left[\left(\sum B s\right) \times A A U_{m=j}^{\mathrm{n} 1}\right]_{s=i}^{n} \sum A A U(4)_{m=j}^{\mathrm{n} 1}
$$

Bs- is the Braun-Blanquet class biodiversity score of species $\mathrm{s}$

AAU-agricultural area used of the unit under observation (in case we are using formula for all the farm $\Sigma \mathrm{AAU}=\mathrm{FA}$ )

$\mathrm{n}$-number of the species observed

farm

$\mathrm{n}_{1}$-number of the fields or sites included respectively in the site or in the

The Arbours plant biodiversity indicator (ABI) takes into consideration the natural habitats. The objective of this indicator is to evaluate the coverage of forest and small isolated natural forest habitats in relation to the total farm area. Determination of their area coverage and other characteristics of these natural habitats is done on the map and through observations on the field.

The formula used for the calculation of this indicator is:

$$
\mathrm{APB}=\Sigma(\mathrm{S} \times \mathrm{SDC} \times \mathrm{WTC}) / \mathrm{AAU}(5) \text { (Lazzerini et al, 2002) }
$$

$\mathrm{S}$-is the surface of the forest habitats

SDC- is the Spatial Distribution Coefficient

WTC -is Wood (Forest) Typology Coefficient

The Ecological Infrastructure Indicator (EII) evaluates the level of farm hedges presence and other ecological infrastructures. "Ecological infrastructure is made up of linear and non-linear elements. Cover crops, border planting, uncultivated patches of vegetation and stonewalls contribute to ecological infrastructure" (Kabourakis and Vassiliou, 2000).

Cultivated hedges do not exist on both farms, but a very similar role can be given to stonewalls. Stonewalls are included in this indicator too. Because of their nature that is the same like heaps of stone (but they are quite solid) they let the water go trough and keep the soil. The well developed network of walls in these farms plays a good role as hedges infrastructure even because the majority of them are re-naturalised with herbaceous spontaneous plants and shrubs. The wall length data where collected by measuring walls on the farm with a Total Station TOPCON 1400 and reporting them on the maps

The Nitrogen Surplus Indicator(NSI) is calculated through the black box budget. The concept of the black box budget is that we have to consider all the inputs enter in our agro-ecosystem for elements we are interested to study and all outputs go out of the system. The nitrogen surplus is defined as the difference between input and output of nitrogen per hectare per year (Hanegraaf, 1998). 
This indicator is calculated first at site level since both of farms use uniform techniques according to their site level. The weighted mean of the site indicators is calculated for the farm level indicator.

The Phosphorus Surplus indicator is calculated for the same reason and in the same way the nitrogen surplus indicator is calculated.

The Environmental Potential Risk Indicator for Pesticides (EPRIP) aims to evaluate the potential hazard of pesticides for soil, groundwater (by leaching), surface water (by drift and run-off) and air (by volatilisation). EPRIP considers the pesticide risk to humans coming by groundwater and volatilisation, to earthworms in the soil, to fish, algae and crustaceans in surface water by drift and run-off. This indicator is calculated based on comparison of predicted environmental concentration (PEC) estimated, with toxicological parameters. (PAN, 2003).

The EPRIP model software was used to calculate the indicator. (Trevisan et al., 1999 ; Reus et al, 2002 ; Padovani et al, 2004). The model does the estimation of the pesticide risk at farm, crop and field-level (Reus et al. 2002; Padovani et al, 2004). In our case, since the agronomical practices and especially pesticide treatments are done uniform for each site, the estimation is done in site-level and then aggregated at farm level.

Table 4. EPRIP input data (Source: Pacini, 2003)

\begin{tabular}{|c|c|}
\hline $\begin{array}{l}\text { Input } \\
\text { group }\end{array}$ & put data \\
\hline $\begin{array}{l}\text { Active } \\
\text { ingredients }\end{array}$ & $\begin{array}{l}\mathrm{LC}_{50} \text { for fishes, } \mathrm{LC}_{50} \text { for daphnia, } \mathrm{LC}_{50} \text { for earthworms, } \mathrm{LC}_{50} \text { for rats, } \\
\text { application rate solubility in water, } \mathrm{DT}_{50} \text {, absorption coefficient in organic matter } \\
\left(\mathrm{K}_{\text {oc }} \text {, Henry's law constant, molecular weight, vapour pressure. }\right.\end{array}$ \\
\hline Soil & $\begin{array}{l}\text { Bulk density, soil organic carbon content, slope, water table depth, sand } \\
\text { percentage, field capacity. }\end{array}$ \\
\hline Climate & $\begin{array}{l}\text { Annual rainfall, maximum daily rainfall in the survey period, net water table } \\
\text { recharge, number of days with rainfall events higher than } 30 \mathrm{~mm}\end{array}$ \\
\hline Draina & Ditch depth and wide \\
\hline Crop & $\begin{array}{l}\text { Incorporation depth, number of the applications, interval between applications, } \\
\text { type of crop behaviour for run-off, average distance between crop and ditches, } \\
\text { type of crop behaviour for drift, crop stage, type of crop behaviour for } \\
\text { interception. }\end{array}$ \\
\hline
\end{tabular}

EPRIP values for each pesticide application is calculated using sitespecific input data on pesticide properties (persistence and mobility in the soil, and toxicity), application rates and application time, crops, soils (bulk density, organic matter, water permeability, field capacity, distance from surface and groundwater, rainfall, temperature and ditches (Reus et al., 1999; Reus and Leendertse, 2000). 
The pesticide have a range of EPRIP between 1 to 825 points: those with higher EPRIP will have higher potential risk to the environment and human being. (Padovani et al, 2004).

Table 5. EPRIP classification (Source: Padovani et al., 2004)

\begin{tabular}{|ccc|}
\hline $\begin{array}{c}\text { Cla } \\
\text { ss }\end{array}$ & $\begin{array}{c}\text { EPRIP } \\
\text { value }\end{array}$ & $\begin{array}{c}\text { Potential risk } \\
\text { classification } \\
\text { None }\end{array}$ \\
\hline $\mathbf{1}$ & 1 & Negligible \\
\hline $\mathbf{2}$ & $2-16$ & Low \\
\hline $\mathbf{3}$ & $17-81$ & Intermediate \\
\hline $\mathbf{4}$ & $82-256$ & High \\
\hline $\mathbf{5}$ & $257-400$ & Very high \\
\hline
\end{tabular}

Data obtained from calculation of environmental indicators are compared with reference thresholds reported from scientific literature or are regulated by legislation.

Table 6. Some indicator thresholds

\begin{tabular}{|c|c|c|c|c|}
\hline $\begin{array}{l}\mathbf{N} \\
\mathbf{r}\end{array}$ & Indicator & EST & $\begin{array}{l}\text { Sour } \\
\text { ce }\end{array}$ & $\begin{array}{l}\text { EST }^{2} \text { model } \\
\text { equivalent }\end{array}$ \\
\hline 1 & Nitrogen leaching & $50 \mathrm{mg} / 1$ & (a) & $27 \mathrm{~kg} \mathrm{~N} / \mathrm{ha}$ \\
\hline 2 & Nitrogen run-off & $50 \mathrm{mg} / 1$ & (a) & $11 \mathrm{~kg} \mathrm{~N} / \mathrm{ha}$ \\
\hline 3 & Soil erosion & $<1.5 \mathrm{t} / \mathrm{ha}$ & (b) & $<1.5 \mathrm{t} / \mathrm{ha}$ \\
\hline 4 & HPBI & 50 species/farm & (c) & 48 HPBI score/ha \\
\hline 5 & Soil organic matter & $>2.5 \%$ & (i) & \\
\hline 6 & $\begin{array}{l}\text { Soil organic mater } \\
\text { input/output }\end{array}$ & $>1$ & (k) & \\
\hline 7 & A PB & $5 \%$ & (d) & $5 \%$ \\
\hline 8 & HL(EII) & $\begin{array}{c}1000-2000 \mathrm{~m} / 25 \\
\text { ha }\end{array}$ & (e) & $60 \mathrm{~m} / \mathrm{ha}$ \\
\hline 9 & $\begin{array}{l}\text { Surface water balance in dry } \\
\text { season }\end{array}$ & $0 \mathrm{~m}^{3} / \mathrm{ha}$ & (f) & $0 \mathrm{~m}^{3} / \mathrm{ha}$ \\
\hline 10 & EPRIP & 81 scores $/$ ha & (g) & 81 scores $/$ ha \\
\hline 11 & ALDI & - & (h) & 30 scores $/$ ha \\
\hline
\end{tabular}

Source Legend: (a) EU directive 91/676; (b) Pimentel et al., 1995 ; Kabourakis, 1996 ; (c), (d), (e), (h) and (k) Verejken, 1999 ; (f) D.L. (Italian law by decree) 152/1999; (g) Trevisan et al.,1999, EU directive $91 / 414$; (i) Van Mansvelt, \& van der Lube, 1999.

2 EST model equivalent, referred to Pacini et al., 2002 
The Gross Margin as financial accountancy system indicator has the goal to perform a financial assessment of different farm management systems, conventional and organic. It is not intended to produce a whole evaluation of farm economic aspects. However, it takes into account some important short-term aspects such as revenues and variable costs. In the revenues is included the monetary flows due to selling of the different products and subsidies or payments for different environmental services. Variable costs refer to all farming practices, singularly considered.

\section{Results and discussion}

Results collected from measurements and indicator calculations are presented for both farms in the table 7. The indicators showed in the table represent aggregated indicators in farm level. The same indicators are calculated for each site: this data can have more importance for farmers themselves in order to understand which are agronomical techniques to be favored or not depending on results obtained. The farm indicators presented in the table are compared with thresholds.

Water use indicator, shows that both farms use irrigation water efficiently (there is not loss of water from irrigation). The delivered water is not sufficient for plant needs. The real motivation behind these values is that water resources are scarce and farmers use the under-ground water for irrigation. Since water used is coming from the groundwater-table, taken through pitfalls, there is a limit in using it; in fact, the quantity of water taken out from the water table has not to be higher than its recharge. The organic farm indicator is far below the threshold value compared to conventional farm.

Soil erosion indicator as a weighted average showed moderate level. From results of single field and sites was observed that potential risk for erosion depended on topographical factor in organic farm was much higher because of higher pendency. This factor is corrected by soil coverage which is depended on agronomic techniques in organic farm.

Soil organic matter and input/output indicators show that both farms have the same values and better performance than the threshold values. They take care to adopt practices that increase soil organic matter content; the input/output ratio shows that agronomical practices adopted by organic farm are much better presenting a strong condition for further increase of organic matter in soil. Organic farm have a surplus of organic matter $732.7 \mathrm{~kg} / \mathrm{ha}$ in a year against $108.1 \mathrm{~kg} / \mathrm{ha}$ of conventional farm or three times more.

Biodiversity indicators assessed are four as presented in the table 7. Except for ALDI that is zero for both farms, the organic farm shows better performance for EII, APBI and HPBI. 
Table 7. Farm indicators and thresholds

\begin{tabular}{|lccc|}
\hline Environmental indicator & $\begin{array}{c}\text { Il Frantoio } \\
\text { conv farm }\end{array}$ & $\begin{array}{c}\text { Serenerba } \\
\text { org farm }\end{array}$ & $\begin{array}{c}\text { Threshold } \\
\text { value }\end{array}$ \\
\hline Water use (mc/ha AAU) & 0,34 & 0,04 & $\leq 1$ \\
\hline Potential risk of soil erosion (risk class) & moderate & moderate & low \\
\hline Soil organic matter content (\%) & 3,06 & 3,13 & $>2,5$ \\
\hline Soil organic matter input/output & 2,1 & 6,9 & $>1$ \\
\hline Agricultural lanscape diversity (score/ha) & 0 & 200,24 & 30 \\
\hline $\begin{array}{l}\text { Herbaceous Plant Diversity (score/ha } \\
\text { AAU) }\end{array}$ & 162,44 & 7,24 & $>48$ \\
\hline $\begin{array}{c}\text { Arboreous plant biodiversity (\% total } \\
\text { farm area) }\end{array}$ & 6,34 & 896,15 & $>60$ \\
\hline Ecological Infrastructure (m/ha AAU) & 643,40 & $-13506,41$ & 50 \\
\hline Farm nitrogen surplus (kg N/ha AAU) & $-51121,15$ & $-792,75$ & 20 \\
\hline $\begin{array}{l}\text { Farm phosphorus surplus (kg } \mathrm{P}_{2} \mathrm{O}_{5} / \mathrm{ha} \\
\text { AAU) }\end{array}$ & $-24020,22$ & 74,44 & $<81$ \\
\hline $\begin{array}{c}\text { Environmental potential risk of pesticide } \\
\text { use (score/ha AAU) }\end{array}$ & 600 & $€ 1.308,22$ & $\begin{array}{c}\text { No } \\
\text { threshold } \\
\text { value }\end{array}$ \\
\hline \begin{tabular}{l} 
Gross margin (€/ha AAU) \\
\hline
\end{tabular} & $€ 1.108,96$ & & \\
\hline
\end{tabular}

Nutrient surplus indicators (nitrogen and phosphorus) show that both farms through agronomical practices add less nutrients than loses through production: this means that both farms likely are not source of water-table pollution. The other observation is that agronomical techniques applied in organic farm tend to impoverish the soil much less than the conventional farm.

EPRIP presented in the table presents farm values that are weighted mean of field and site values. Organic farm performs much better than the conventional farm: the risk generated by organic farm is lower than 81 score $(74.4$ score entering in low potential risk) while conventional farm have a 600 score potential risk. In this specific case organic farm was interested by 1 treatment with Copper Oxychloride while the conventional farm uses 5 insecticides and 1 herbicide explaining the very high EPRIP values.

Gross margin has not threshold values to be compared. The gross margin/ha AAU in organic farm is higher than in conventional. Their difference could be much higher if the organic farm did not have lower revenues from environmental payments and extra cost for ecological infrastructure maintenance (table 8). Its revenues from production are much higher than those of 
conventional farm (thanks to higher prices even there is a $12 \%$ reduction of production of olives compared to conventional farm)

Table 8. Revenues, Variable cost and Gross Margin

\begin{tabular}{|c|c|c|c|c|c|}
\hline \multicolumn{2}{|c|}{ Financial indicators } & \multicolumn{2}{|c|}{$\begin{array}{l}\text { Il Frantoio conv. } \\
\text { farm }\end{array}$} & \multicolumn{2}{|c|}{ Serenerba org. farm } \\
\hline & & $\begin{array}{l}\text { Value } \\
€\end{array}$ & $\begin{array}{l}\text { value/ha } \\
\text { AAU } €\end{array}$ & $\begin{array}{l}\text { Value } \\
€\end{array}$ & $\begin{array}{l}\text { value/ha } \\
\text { AAU } €\end{array}$ \\
\hline \multirow{4}{*}{ Revenues } & Products & $\begin{array}{l}64.840 \\
33\end{array}$ & $1.328,21$ & $\begin{array}{l}40.33 \\
6,59\end{array}$ & $1.965,87$ \\
\hline & $\begin{array}{l}\text { Agro-environmental } \\
\text { payments }\end{array}$ & $\begin{array}{l}20.264 \\
65\end{array}$ & 415,11 & $\begin{array}{l}9.097 \\
38\end{array}$ & 443,38 \\
\hline & Compensation payments & $\begin{array}{l}28.350 \\
27\end{array}$ & 580,74 & $\begin{array}{l}5.245, \\
36\end{array}$ & 255,64 \\
\hline & Total & $\begin{array}{l}113.45 \\
5,25\end{array}$ & $2.324,06$ & $\begin{array}{l}54.67 \\
9,33\end{array}$ & $2.664,89$ \\
\hline \multirow{5}{*}{$\begin{array}{l}\text { Variable } \\
\text { cost }\end{array}$} & olive production & $\begin{array}{l}39.972 \\
49\end{array}$ & 818,81 & $\begin{array}{l}12.23 \\
0,33\end{array}$ & 596,07 \\
\hline & transformation cost & $\begin{array}{l}4.561,2 \\
0\end{array}$ & 93,43 & $\begin{array}{l}1.005, \\
69\end{array}$ & 49,01 \\
\hline & Forage & $\begin{array}{l}14.784 \\
65\end{array}$ & 302,85 & $\begin{array}{l}8.232 \\
50\end{array}$ & 401,23 \\
\hline & $\begin{array}{c}\text { Ecological infrastructure } \\
\text { payment }\end{array}$ & & - & $\begin{array}{c}6.368 \\
17 \\
\end{array}$ & 310,36 \\
\hline & Total & $\begin{array}{l}59.318 \\
35\end{array}$ & $1.215,10$ & $\begin{array}{l}27.83 \\
6,69 \\
\end{array}$ & $1.356,67$ \\
\hline $\begin{array}{c}\text { Goss } \\
\text { margin }\end{array}$ & & $\begin{array}{l}54.136, \\
90\end{array}$ & $1.108,96$ & $\begin{array}{l}26.84 \\
2,65\end{array}$ & $1.308,22$ \\
\hline
\end{tabular}

\section{Conclusions}

Comparison of two olive growing farms of two different agricultural systems, organic and conventional demonstrated different results for some of indicators used as instrument of comparison. The differences confirmed a better performance of organic compared to conventional farm especially for indicators like organic matter input/output, nutrient surplus and EPRIP. There are indicators linked to agronomic techniques especially to ecological infrastructure and soil coverage that are very similar: this confirms the benefit of land management and conservation techniques considering that conventional farm was near to organic farm in a very extensive area and did not use very intensive practices. 


\section{References}

Allen, R. G. Perejra, L.S., Paes, D. \& Smith, M. (1998). Crop evapotranspiration. Guidelines for computing crop water requirements. FAO irrigation and drainage paper 56. Roma. Also available on-line on http://www.fao.org/docrep/X0490E/x0490e0b.htm [last consultation 13.02.2013].

Beals, M., Gross, L. \& Harrell, S. (2000). Diversity indices: Shannon's H and E. The Institute for Environmental Modelling (TIEM).University of Tennessee. Electronic source: http://www.tiem.utk.edu. [last consultation 21.09.2012].

Becher, H.H. (2003). Estimating soil loss due to erosion by water and wind Wissenschaft Zentrum Weihenstephan.Technische Universität Munchen. Electronic source. http://www.wzw.tum.de/bk/pdfs/uebungen/erosion.pdf [Last date of consultation: 21.01.2013].

Hamdy, A. (1997). Laboratori techniques. Mediterranean Institute of Bari. CIHEAM. Italy

Hanegraaf, M.C. (1998). Environmental performance indicators for nitrogen. Environmental Pollution. Elsevier. 102, $\mathrm{S}_{1}$. 711-715.

Kabourakis, E. (1996). Prototopyng and dissemination of ecological and productive system:A methodology for designing and a first step towards validation and dissemination of prototype ecological olive production system (EOPS) in Crete. Ph.D thesis Wageningen Agricultural University, Wageningen, Netherlands.

Kabourakis, E. \& Vassiliou, A. (2000). Designing and disseminating ecological production systems for the perennials. A first step for developing sustainable organic farming for the Mediterranean. Proc. FAO Working Group on Organic Farming, 23-26 September 1998, FiBL Research Institute, Switzerland. REU Technical Series 53, FAO Italy.

Lazzerini, G. et al., (2002). Contamb 2002, Software di contabilità ambientale. Manuale dell'utente. Associazione Ambiente Lavoro Toscana- ONLUS, Italy.

Myristica - mensile di botanica e natura on line (2002). Vegetazione, metodi di rilevamento.Electronic source. http://www.myristica.it/jun2002/vegetazione2.html. [last date of consultation 25.02.2010]

Pacini C. et al., (2002). The modelling framework. In: Pacini, C., Economicenvironmental accounting

and modelling to evaluate sustainability of farming systems for multi-objective policymaking. Ph.D thesis Wageningen University, Wageningen, The Netherlands.

Pacini C.G. (2003). An environmental-economic framework to support multi-objective policymaking. A farming systems approach implemented for Toscany. Ph.D thesis, Wageningen, Netherlands.

Pacini, G. C., Lazzerini, G. \& Vazzana, C. (2011). AESIS: a support tool for the evaluation of sustainability of agroecosystems. Example of applications to organic and integrated farming systems in Tuscany, Italy. Italian Journal of Agronomy, 6, (1), 185-191. 
Padovani L., Trevisan, M. \& Capri E. (2004). A calculation procedure to assess potential environmental risk of pesticides at farm level. Ecological Indicatros. Elsevier. 4: 111-123.

Pesticide Action Network North America (PAN) (2003). Identification, toxicity, use, water pollution potential, ecological toxicity and regulatory information for pesticides. PAN Pesticides Database-Chemicals. Electronic source:

http://www.pesticideinfo.org/Detail_Chemical.jsp?Rec_Id=PC35730.

[ last consultation 04.10.2004].

Pileri, P. (1992. Interpretare l'ambiente - Gli indicatori di sostenibilità per il governo del territorio. Alinea Editrice, Firenze, Italy.

Pimentel, D. \& Harvey, C. (1995). Environmental and economic costs of soil erosion and conservation benefits. Science 267, 1117-1121.

Reus, J., Leendertse, P., Bockstaller, C, Fomsgaard, I., Gutsche, V., Lewis, K., Nilsson, C., Pussemier, L., Trevisan, M., Van der Verf, H., Alfarroba, F., Blumel, S., Isart, J., McGrath, D. \& Seppala, T. (1999). Comparing environmental indicators for pesticide-Results of the European CAPER project. Center for Agriculture and Environment, Utrecht, The Netherlands.

Reus, A.W.A.J. \& Leendertse, C.P. (2000). The environmental yardstick for pesticides: a practicalindicator used in Netherlands. Crop Protection. Elsevier. 19: 637-641.

Reus, J., Leendertse, P., Bockstaller, C, Fomsgaard, I., Gutsche, V., Lewis, K., Nilsson, C., Pussemier, L., Trevisan, M., Van der Verf, H., Alfarroba, F., Blumel, S., Isart, J., McGrath, D. \& Seppala, T. (2002). Comparison and evaluation of eight pesticide environmental risk indicators developed in Europe and recommendations for future use. Agricultural Ecosystems \& Environment. Elsevier. 90: 177-187.

Ritter, E. M. (2004). Soil texture triangle. The Physical Environment. Software. Electronic source: http://www.uwsp.edu/geo/faculty/ritter/geog101/textbook/title page.html [last date of consultation 12.07.2004]

Saxton, E. K. (2003). Soil water characteristics. Hydraulic properties Calculator. USDA. Software. Electronic source.

http://www.bsyse.wsu.edu/saxton/soilwater/Register.htm?Download [last date of consultation 21.08.2004]

Trevisan M. et al., (1999). Environmental Potential Risk Indicator for Pesticides. In Reus et al., Comparing Environmental Risk Indicator for Pesticides- Results of the European CAPER Project. Center for Agriculture and Environment, Utrecht, The Netherlands.

United States Department of Agriculture(USDA), (2001). Soil texture triangle, Hydraulic properties calculator. Software. Electronic source.

http://wilkes1.wilkes.edu/ boram/soilwatr.htm?177,153. [last consultation 12.07.2004]

Van der Knijft, J.M., Jones, R.J.A. \& Montanarella, L. (1999). Soil erosion risk assessment in Italy. European Soil Bureau, European Comission, Ispra, Italy.

Van Mansvelt, J.D. \& van der Lube, M.J. (1999). Checklist for sustainable Management. Elsevier, Amsterdam 
Vazzana C., Raso E. \& Pieri S., (1997). Una nuova metodologia europea per la progettazione e gestione di agroecosistemi integrati ed ecologici: applicazione in un'area agricola Toscana. Rivista di Agronomia 31:423-440.

Vereijken, P. (1999). Manual for prototyping integrated and ecological arable farming systems (I/EAFS) in interaction with pilot farms. AB-DLO, Wageningen, The Netherlands.

Wischmeier, W.H. \&Smith, D.D. (1978). Predicting rainfall erosion losses- a guide for conservation planning. U.S Department of Agriculture, Agriculture Handbook 537.

\section{Other Source}

ACLA 2-Project (2001). Agro-ecological Characterization of the Apulia region by means of Potential Productivity . Mediterranean Agronomic Institute of Bari, Apulia Region. Italy 